\title{
WES Reveals Novel Heterozygous NBAS Gene Mutations Associated with Fanconi Syndrome in a Patient with SOPH Syndrome: Case Report
}

\author{
Jia Yean Thong ${ }^{1 \#}$, Zifeng $\mathrm{Li}^{2 \#}$, Alice Halim ${ }^{1 \#}$, Xiaochuan Wang ${ }^{3}$, Michael Halim ${ }^{4}$, Xiaowen Zhai $^{2^{*}}$ \\ ${ }^{1}$ Zhongshan Hospital, Shanghai Medical College of Fudan University, Shanghai, China \\ ${ }^{2}$ Department of Hematology and Oncology, Children's Hospital of Fudan University, China \\ ${ }^{3}$ Department of Immunology, Children's Hospital of Fudan University, China \\ ${ }^{4}$ University of Salford, MSc Biomedical Science, Greater Manchester, United Kingdom
}

Corresponding Author(s): Michael Halim* and Xiaowen Zhai ${ }^{* *}$

Address: *University of Salford, MSc Biomedical Science, Greater Manchester, United Kingdom. **Department of Hematology and Oncology, Children's Hospital of Fudan University, No. 399 Wanyuan Rd, Minhang District, Shanghai 201102, China.

Received date: 11 January 2021; Accepted date: 12 February 2021; Published date: 20 February 2021

Citation: Thong JY, Li Z, Halim A, Wang X, Halim M, Zhai X. WES Reveals Novel Heterozygous NBAS Gene Mutations Associated with Fanconi Syndrome in a Patient with SOPH Syndrome: Case Report. Asp J Pediatrics Child Health. 2021 Feb 20;3(1):1-10.

Copyright (C) 2021 Thong JY, Li Z, Halim A, Wang X, Halim M, Zhai X. This is an open-access article distributed under the Creative Commons Attribution License, which permits unrestricted use, distribution, and reproduction in any medium, provided the original work is properly cited.

\begin{abstract}
Variations in the NBAS gene is known to cause a spectrum of phenotypes ranging from isolated recurrent acute liver failure (RALF) to a multisystemic presentation known as SOPH syndrome. Patients with SOPH present with optic atrophy, acute liver failure, short stature, and Pelger-Huet anomaly. We report the presence of a novel pair of biallelic heterozygous mutations c.5139-5 $\mathrm{T}>\mathrm{G}$ and c.2203-2A $>\mathrm{G}$ in the NBAS gene of a patient with SOPH syndrome. A 9-year-old patient was clinically diagnosed with SOPH following clinical laboratory analyses. Current interventions for managing the disease encompass IVIG, methylprednisolone, calcium, and vitamin D administration. Whole-exome sequencing (WES) results showed two mutations: c.2203-2A $>$ G and c.5139-5T $>$ G, in the NBAS gene, which had not been previously reported. Notably, we hypothesize that NBAS mutations could potentially contribute to the development of Fanconi syndrome, a clinical diagnosis reported in our patient. Our study also supports the renaming of SOPH to SOPHIA to allow early detection and effective treatment.
\end{abstract}

\section{Keywords}

Short Stature, Optic Atrophy, Pelger-Huet Anomaly, Neuroblastoma Amplified Sequence, Mutation, WholeGenome Sequencing, Myopia, Case Report, Acute Liver Failure, Fanconi Syndrome

\section{Introduction}

Autosomal recessive short stature with optic atrophy and Pelger-Huet anomaly (SOPH) syndrome arises from biallelic pathogenic variants in the NBAS (neuroblastoma amplified sequence) gene. SOPH syndrome is characterized by small hands, postnatal retardation, optic atrophy, loss of color vision, senile facial appearance, and loss of normal intelligence [1]. Moreover, SOPH is characterized by key clinical indicators such as optic atrophy, Pelger-Huet anomaly, and short stature [2]. Patients with SOPH syndrome exhibit recurrent episodes triggered by fever with dehydration, elevated transaminases, and vomiting [3]. Haack et al. [4] reported the presence of biallelic 
Citation: Thong JY, Li Z, Halim A, Wang X, Halim M, Zhai X. WES Reveals Novel Heterozygous NBAS Gene Mutations Associated with Fanconi Syndrome in a Patient with SOPH Syndrome: Case Report. Asp J Pediatrics Child Health. 2021 Feb 20;3(1):1-10.

mutations in the NBAS gene, which revealed heterozygous mutations and reduced NBAS proteins. Recurrent acute liver failure (RALF) is a complication associated with SOPH syndrome [5-7]. Maksimova, Nogovicina, Kutanov, and Alekseeva [8] identified the c.G57G41>A mutation in the NBAS gene as the primary cause of the underlying defects in SOPH syndrome. We present a case of a 9-year-old Chinese female with SOPH syndrome following an analysis of the mutations on the NBAS gene by whole-exome sequencing (WES).

\section{Case Description}

A 9-year-old patient was referred to Fudan University Children's Hospital, Shanghai, China for persistent abdominal distension. The patient was born to healthy, non-consanguineous parents. At 6-years old, she was referred to Fudan University Children's Hospital due to short stature, immunodeficiency, pneumonia, and low white blood cells counts. The patient also presented with thin body habitus, prominent nasolabial folds, small hands, and large protruding eyes (Fig-1)

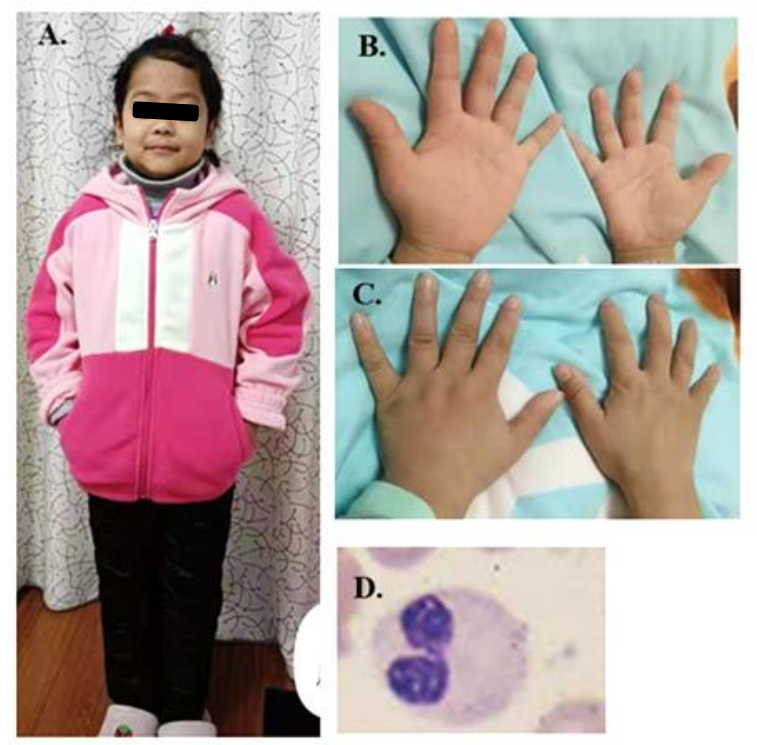

Fig-1:

A 9-year-old patient diagnosed with SOPH. A; Facial dysmorphism was evident as a result of the patient's progeroid features; $B$. Ventral view the of the patients' palms showed brachydactyly; $C$. The dorsal view of the patient showed wrinkled skin at the proximal interphalangeal joints of the fingers; D. Pelger-Huet anomaly.

Complete Blood Count (CBC) revealed low levels of WBC counts $\left(1.41^{*} 10^{9} / \mathrm{L}\right.$ [normal $\left.\left.4-10^{*} 10^{9} / \mathrm{L}\right]\right)$, low neutrophil counts $\left(0.10^{*} 10^{9} / \mathrm{L}\right.$ [normal $\left.2-7^{*} 10^{9} / \mathrm{L}\right)$, low RBC count $\left(3.01^{*} 10^{12} / \mathrm{L}\right.$ [normal 3.5- $\left.5.5 * 10^{12}\right)$ and eosinophilia: EO\% (24.8\% [normal, $0.5-5 \%])$. Immunology studies revealed low levels of $\mathrm{CD}_{3}+$ (37.01\% [normal, 64\%-73\%]), low CD4+ (18.50\% [normal, 29\%-36\%]), low CD4+/CD8+ ratio (o.94 [normal, >1.0), low CD8+ (19.69\% [normal, 24\%$34 \%])$ and low $\mathrm{NK}\left(\mathrm{CD}_{5} 6+\right)$ cells [6.69 [normal, 11\%-23\%]). The levels of $\mathrm{B}$ lymphocytes were however elevated (52.76\% [normal, 14\%-21\%]). Bone marrow aspiration revealed Pelger-Huet anomaly of the neutrophil granulocytes, myeloid hyperplasia (erythrocyte lineage: 21.60\%; granulocyte lineage: $61.20 \%)$, and scarce platelets.

Results of her fundus and visual evoked potential exams revealed no visual acuity changes, which ruled out optic atrophy. Her height, weight and BMI details at age 7 years old were as follows: Height: $107.10 \mathrm{~cm}$ [<-3 SDs]; Weight: $15.80 \mathrm{~kg}$ [< -3 SDs]; BMI: 13.77 $\mathrm{kg} / \mathrm{m}^{2}$ [<-1 SDs] (Fig-2). Moreover, her most recent bone scans revealed that she did not have osteoporosis.

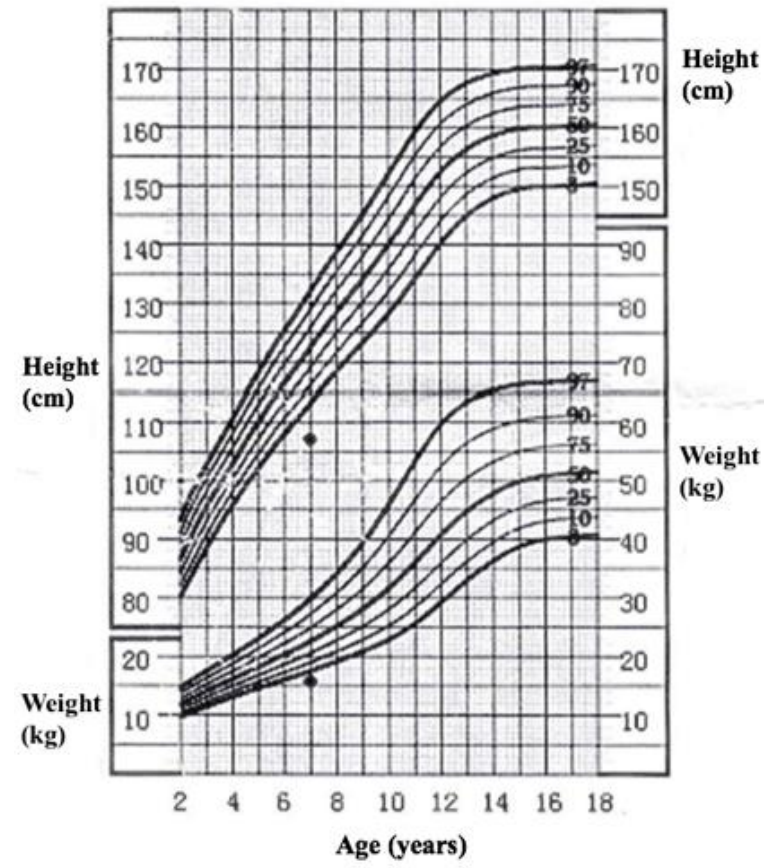

Fig-2: Evaluation of the patient's growth and development.

The patient's records presented by her parents indicated frequent episodes of upper respiratory tract infections and hives. Moreover, the pregnancy, birth, and postnatal period were uneventful. At 3 years old, 
the patient was hospitalized for ascites, acute bronchitis, and pleural effusion. She also presented with recurrent fevers over a period of one month. Abdominal distension, chronic cough, and occasional abdominal pain were also evident upon admission. Serum chemistry profile revealed hypophosphatemia, mildly elevated CK and AST levels. However, the levels of ALT were within normal range and her coagulation studies were normal. Abdominal ultrasound revealed presence of fluid in the pleural and pelvic cavities, enlarged liver and spleen, and a thickened Glisson capsule. The patient also exhibited relatively low levels of IgA, IgM, low complement $\mathrm{C}_{3} \mathrm{C}$ and $\mathrm{CD}_{4+/ \mathrm{CD} 8+}$ levels, suggesting weakened immunity. Upon her discharge from the hospital, her symptoms improved following antibiotic therapy. During her outpatient follow up, her CBC revealed markedly low levels of WBCs, RBCs, neutrophil counts and anaemia with low haemoglobin which prompted another hospitalisation.

During the course of her hospitalisation, her haemoglobin levels further decresed for reasons unknown which warranted blood transfusion of washed blood when it reached $53 \mathrm{~g} / \mathrm{L}$ [normal, 110-16o $\mathrm{g} / \mathrm{L})$. The patient was also diagnosed with Hashimoto's thyroiditis upon thyroid function examination which revealed markedly elevated thyroglobulin and antiTPO antibodies. As such, she received levothyroxine treatment and follow-ups.

At age 5, she was hospitalised with acute exudative tonsillitis and an EBV infection. The serum chemistry profile revealed elevated levels of ALT, AST, LDH while albumin, globulin, retinol-binding protein, phosphorus and BUN levels were very low, suggesting a damaged liver.

To further investigate the cause of her clinical findings, WES was performed. Two important mutations were revealed upon sequencing the NBAS gene. The patient's genotypic data revealed two heterozygous splice-site mutations in the NBAS gene (Table-1)

The data for this WES is obtained from the genetics department of the Children's Hospital, Fudan University, Shanghai, China, and is successfully registered in the Genome Sequence Archive in BIG Data Center, Beijing Institute of Genomics (BIG, http://gsa.big.ac.cn), Chinese Academy of Sciences, with Project Accession No. HRAooo627.

\begin{tabular}{|c|c|c|c|c|c|c|c|c|}
\hline \multicolumn{9}{|c|}{ Table-1: The patient's data showing genotypic information } \\
\hline Gene & Chr & GM information & Zygosity & Disease name & Inheritance & $\begin{array}{c}\text { ExAC } \\
\text { Het/Hom }\end{array}$ & $\begin{array}{c}\text { HGMD } \\
\text { classification }\end{array}$ & $\begin{array}{c}\text { Source } \\
\text { variation }\end{array}$ \\
\hline NBAS & chr2: 15417230 & $\begin{array}{l}\text { NM_o159og:exon43: } \\
\text { c.5139-5T>G }\end{array}$ & Het & $\begin{array}{l}\text { Infantile liver failure syndrome } 2 \text {, } \\
\text { [MIM:616483]; Short stature, optic } \\
\text { nerve atrophy, and Pelger-Huet } \\
\text { anomaly, [MIM:61480o] }\end{array}$ & $\begin{array}{l}\text { Autosomal } \\
\text { Recessive }\end{array}$ & o|o & - & Paternal \\
\hline NBAS & chr2: 15601463 & $\begin{array}{l}\text { NM_0159o9:exon21: } \\
\text { c. } 2203-2 \mathrm{~A}>\mathrm{G}\end{array}$ & Het & $\begin{array}{l}\text { Infantile liver failure syndrome } 2 \text {, } \\
\text { [MIM:616483]; Short stature, optic } \\
\text { nerve atrophy, and Pelger-Huet } \\
\text { anomaly, [MIM:61480o] }\end{array}$ & $\begin{array}{l}\text { Autosomal } \\
\text { Recessive }\end{array}$ & o|o & - & Maternal \\
\hline
\end{tabular}

At the age of 7 years, the patient presented with mucosal bleeding and hepatosplenomegaly. Lab evaluations revealed severe thrombocytopenia (platelet: $11^{\star} 10^{9} / \mathrm{L}$ ) and Fanconi syndrome with proximal renal tubular acidosis (RTA). The patient also had low 25-hydroxy vitamin D (9.56 mg/mL) with normal PTH levels. Nonetheless, her renal ultrasound was unremarkable. She received washed blood transfusion due to thrombocytopenia and low hemoglobin levels.

Between ages 4 and 8, she had 18 episodes of recurrent infections requiring the administration of IVIG due to her immunodeficiency. The patient was subjected to antipyretic therapy for fever reduction following IVIG therapy, enlarged liver, and to prevent 
acute liver failure. Over the past year, she was also given steroids, vitamin $\mathrm{C}$ and calcium to manage her condition.

\section{Discussion}

Hereditary short stature syndrome is a genetically heterogeneous condition that has been prevalent among Yakuts in Asia [9]. Even though most of the patients with SOPH syndrome have been known to present with short stature, Pelger-Huet anomaly, optic atrophy and liver failure due to mutations in the NBAS gene $[10,11]$, several other mutations in the NBAS gene can also result in abnormal liver functions [12]. The aetiology of these mutations is attributed to recurrent episodes of liver failure, short stature, Pelger-Huet anomaly, and optic atrophy [7,13-15].

We hypothesised that the novel NBAS mutations in our patient can potentially explain her abnormal liver function, which was evident by elevated levels of AST, ALT, LDH and markedly low levels of albumin, BUN, retinol-binding proteins, and globulin. Additionally, our patient developed Fanconi syndrome, with hypophosphatemia since an early age being one of the main clinical indicators [16], unravelling the potential association of NBAS mutations with Fanconi syndrome. Keefe and Nokhari [17] previously reported genetic changes that contributed to the development of Fanconi syndrome; the absence of the NBAS gene in the report supports the possibility of NBAS mutations having important implications to Fanconi syndrome. (WES) of our patient revealed a paternal mutation c.5139-5T > G, which was an intron variant identified as a splice site mutation located 5 nucleotides upstream exon 43. At this position, this variant interacts with the R1NT1 and ZW10 regions of the C terminal, which are involved in cellular transport between the Golgi apparatus and endoplasmic reticulum [18]. The maternal mutation c.2203-2A>G was identified as a splice site mutation in the intron, 2 nucleotides upstream exon 21, where the mRNA region translates to proteins that play a role in the secretory pathway Sec39 domain and the interaction with p31 protein (Fig-3) [18]. Our study showed that these two mutations play important roles in the severity and aetiology of SOPH, as well as liver dysfunction and immunological suppression.

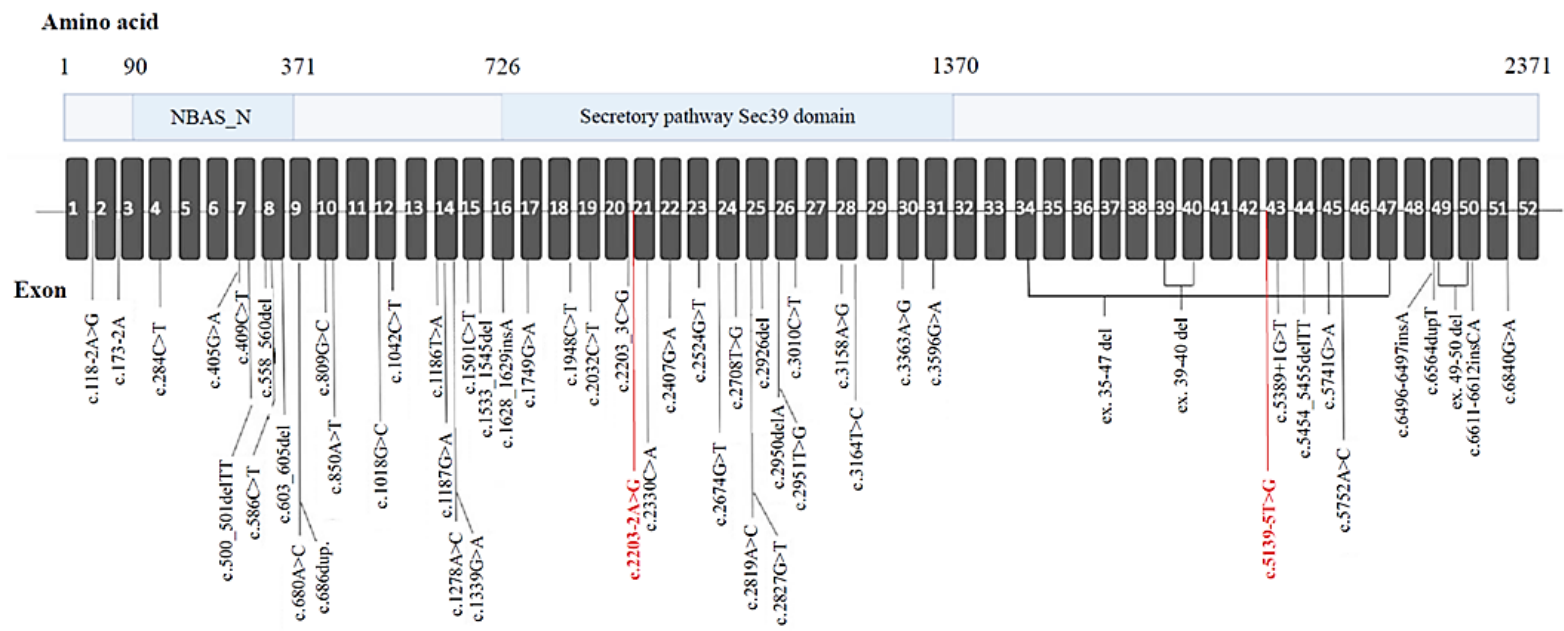

Fig-3: Gene and protein structures of the NBAS and their mutations.

The functional domains and the NBAS proteins are represented in this diagram. These domains encompass the secretory and $N$ proteins, the neuroblastoma-amplified sequence at the $N$ terminal, and the sec 39 domain. Boxes numbered 1 to 52 represent the exons while the lines between the exons are introns. Mutations of the NBAS gene in our current study are shown in red, while NBAS mutations from previous studies are indicated in black.

Several mutations have been previously reported, such as the missense mutations in the NBAS genes, which constitute c.2674G $>$ T, c.1018G $>C$, and the c.5741G $>$ A mutations [19-26]. These mutations affect the evolutionarily conserved amino acids and can be very damaging thus resulting in liver dysfunction and Pelger-Huet anomaly [18]. The current study, however, showed that two additional mutations 
c.5139-5T $>$ G and c.2203-2A $>$ G, which both occurred at introns of the NBAS gene, contributed substantially to the severity of SOPH syndrome by causing abnormal liver function due to changes in liver enzyme levels and immune cells. These changes also revealed the manifestation of Fanconi syndrome in SOPH patients carrying these mutations.

Previous studies employed several other techniques such as genome-wide homozygosity mapping, in silico analysis, Sanger direct sequencing, and western blot analysis for the analysis of these mutations [25-28]. WES was employed in the identification of the generic variants in our study, which had not been previously reported. Nonetheless, we did not follow up the WES results with Sanger sequencing [14], which is considered the gold standard for DNA sequencing. However, Strom et. al. [29] published a study that assessed the accuracy of confirmatory testing by
Sanger sequencing in 144 exome sequences and concluded that their laboratory would discontinue routine Sanger confirmation of exome sequences that meet quality thresholds. They proposed that the slight probability of a genetic variant identified by WES being a false positive is only a minor consideration compared to the uncertainty of genotype-phenotype relationship [29].

Other authors showed how the aetiology of biallelic mutations in the NBAS gene resulted in recurrent episodes of acute liver failure, as shown in our study $[4,6,27,28,30,31]$. Nonetheless, these two mutations were not identified in any of these studies, thus indicating their significance in causing abnormal liver function and Fanconi syndrome in SOPH patients. A comparison of the SOPH mutations in our current study and other studies is shown in Table-2.

Table-2: A comparison between the SOPH mutations in the current study and those reported in the literature

\begin{tabular}{|c|c|c|c|c|c|}
\hline Study & $\begin{array}{c}\text { NBAS } \\
\text { mutation }\end{array}$ & $\begin{array}{c}\text { Notable clinical } \\
\text { features }\end{array}$ & Notable Investigations & $\begin{array}{c}\text { Management / } \\
\text { Treatment }\end{array}$ & $\begin{array}{l}\text { Outcome / } \\
\text { Prognosis }\end{array}$ \\
\hline $\begin{array}{l}\text { Our } \\
\text { study }\end{array}$ & $\begin{array}{l}\text { Heterozygous } \\
\text { P: c.5139-- } \\
5 \mathrm{~T}>\mathrm{G} \mathrm{M} \text { : } \\
\text { c. } 2203^{-2} \mathrm{~A}>\mathrm{G}\end{array}$ & $\begin{array}{l}\text { Facial } \\
\text { dysmorphism; } \\
\text { short stature; } \\
\text { senile skin; } \\
\text { hepatosplenomeg } \\
\text { aly; } \\
\text { developmental } \\
\text { delay }\end{array}$ & $\begin{array}{l}\text { Elevated LFTs with } \\
\text { episodes of pyrexia and } \\
\text { recurrent infections; } \\
\text { pancytopenia; Pelger-Huet } \\
\text { anomaly; reduced T } \\
\text { lymphocytes and NK cells; } \\
\text { renal function } \\
\text { abnormalities (Fanconi } \\
\text { syndrome with proximal } \\
\text { renal tubular acidosis); } \\
\text { bone marrow aspiration } \\
\text { shows myeloid hyperplasia }\end{array}$ & $\begin{array}{l}\text { Antipyretic therapy; } \\
\text { IVIG \& IM Human } \\
\text { thrombopoietin for } \\
\text { thrombocytopenia; } \\
\text { steroids are given } \\
\text { over the past year }\end{array}$ & $\begin{array}{l}\text { Improved } \\
\text { outcome } \\
\text { following } \\
\text { administration of } \\
\text { methylprednisol } \\
\text { one, vitamin D } \\
\text { and calcium. }\end{array}$ \\
\hline $\begin{array}{l}\text { Maksimo } \\
\text { va et al. } \\
{[2]}\end{array}$ & $\begin{array}{l}\text { Homozygous } \\
\text { c. } 5741 \mathrm{G}>\mathrm{A}\end{array}$ & $\begin{array}{l}\text { Facial } \\
\text { dysmorphism; } \\
\text { short stature; } \\
\text { senile skin; bone } \\
\text { dysplasia; } \\
\text { hepatomegaly; } \\
\text { fractures }\end{array}$ & $\begin{array}{l}\text { Pelger-Huet anomaly of } \\
\text { granulocytes; optic nerve } \\
\text { atrophy; achromatopsia }\end{array}$ & Undefined & $\begin{array}{l}\text { Enhanced } \\
\text { growth upon } \\
\text { hormonal } \\
\text { therapy for } \\
\text { correcting short } \\
\text { stature. }\end{array}$ \\
\hline $\begin{array}{l}\text { Segarra } \\
\text { et al. [3] }\end{array}$ & $\begin{array}{l}\text { Heterozygous } \\
\text { P: ex. } 35-47 \\
\text { del. } \\
\text { M: c. } 5741 \mathrm{G}>\mathrm{A}\end{array}$ & $\begin{array}{l}\text { Facial } \\
\text { dysmorphism; } \\
\text { short stature; } \\
\text { senile skin; } \\
\text { developmental } \\
\text { delay; skeletal } \\
\text { dysplasia; bone } \\
\text { fractures; } \\
\text { muscular } \\
\text { hypotonia }\end{array}$ & $\begin{array}{l}\text { Elevated LFTs with } \\
\text { episodes of pyrexia and } \\
\text { recurrent infections; } \\
\text { hypogammaglobulinemia; } \\
\text { low T-cells; low B-cells; } \\
\text { osteoporosis; optic nerve } \\
\text { atrophy; Pelger-Huet } \\
\text { anomaly }\end{array}$ & $\begin{array}{l}\text { Regular IVIG } \\
\text { Immunoglobulin } \\
\text { replacement } \\
\text { therapy; } \\
\text { Bisphosphonates } \\
\text { given to manage } \\
\text { osteoporosis, } \\
\text { physical therapy \& } \\
\text { orthopaedic } \\
\text { recommendations }\end{array}$ & $\begin{array}{l}\text { Improved } \\
\text { immunological } \\
\text { functions } \\
\text { following } \\
\text { immunoglobulin } \\
\text { replacement } \\
\text { therapy and } \\
\text { bisphosphonates. } \\
\text { Overall, there is a } \\
\text { subsequent } \\
\text { improvement in } \\
\text { life expectancy. }\end{array}$ \\
\hline
\end{tabular}




\begin{tabular}{|c|c|c|c|c|c|}
\hline $\begin{array}{l}\text { Haack et } \\
\text { al. [4] }\end{array}$ & $\begin{array}{l}\text { Heterozygous: } \\
\text { c. } 409 \mathrm{C}>\mathrm{T} \\
\text { c.1186T }>\mathrm{A} \\
\text { (undefined } \\
\text { inheritance) }\end{array}$ & $\begin{array}{l}\text { Facial } \\
\text { dysmorphism; } \\
\text { short stature; } \\
\text { senile skin; bone } \\
\text { dysplasia; } \\
\text { hepatomegaly; } \\
\text { fractures }\end{array}$ & $\begin{array}{l}\text { Elevated LFT with episodes } \\
\text { of pyrexia and recurrent } \\
\text { infections; RALF early } \\
\text { infancy; coagulopathy; } \\
\text { hypogammaglobulinemia; } \\
\text { leukopenia; osteoporosis; } \\
\text { small C1-C2 vertebrae } \\
\text { causing cervical instability }\end{array}$ & $\begin{array}{l}\text { Stabilization } \\
\text { surgery to relieve } \\
\text { compression of } \\
\text { cervical spinal cord }\end{array}$ & $\begin{array}{l}\text { Improved life } \\
\text { expectancy upon } \\
\text { relief of pain }\end{array}$ \\
\hline $\begin{array}{l}\text { Capo- } \\
\text { Chichi et } \\
\text { al. [5] }\end{array}$ & $\begin{array}{l}\text { Heterozygous: } \\
\text { c. } 284 \mathrm{C}>\mathrm{T} \\
\text { c. } 850 \mathrm{~A}>\mathrm{T} \\
\text { (undefined } \\
\text { inheritance) }\end{array}$ & $\begin{array}{l}\text { Facial } \\
\text { dysmorphism; } \\
\text { short stature; } \\
\text { senile skin; bone } \\
\text { dysplasia; } \\
\text { hepatomegaly }\end{array}$ & $\begin{array}{l}\text { Elevated LFT with episodes } \\
\text { of pyrexia and recurrent } \\
\text { infections; RALF early } \\
\text { infancy; } \\
\text { hypogammaglobulinemia; } \\
\text { reduced NK cells; } \\
\text { osteoporosis; small C1-C2 } \\
\text { vertebrae causing cervical } \\
\text { instability and myelopathy; } \\
\text { optic atrophy; Pelger-Huet } \\
\text { anomaly }\end{array}$ & $\begin{array}{l}\text { Supportive } \\
\text { management } \\
\text { (Glucose infusion } \\
\text { for hypoglycaemia } \\
\text { during pyrexia and } \\
\text { liver crises); } \\
\text { Mefenamic acid as } \\
\text { antipyretic; weekly } \\
\text { IVIG } \\
\text { Immunoglobulin } \\
\text { replacement } \\
\text { therapy starting } 11 \\
\text { years old; } \\
\text { Stabilization } \\
\text { surgery to relieve } \\
\text { compression of } \\
\text { cervical spinal cord }\end{array}$ & $\begin{array}{l}\text { Reduced } \\
\text { immunological } \\
\text { complications } \\
\text { and disease that } \\
\text { arise from } \\
\text { immunological } \\
\text { defects. }\end{array}$ \\
\hline $\begin{array}{l}\text { Kortüm } \\
\text { et al. [6] }\end{array}$ & $\begin{array}{l}\text { c. } 5741 \mathrm{G}>\mathrm{A} \\
\text { (undefined } \\
\text { zygosity) }\end{array}$ & $\begin{array}{l}\text { Facial } \\
\text { dysmorphism; } \\
\text { short stature; } \\
\text { senile skin; bone } \\
\text { dystrophy; } \\
\text { hypotonia }\end{array}$ & $\begin{array}{l}\text { Elevated LFTs with } \\
\text { episodes of pyrexia; optic } \\
\text { atrophy; complete } \\
\text { achromatopsia }\end{array}$ & Undefined & $\begin{array}{l}\text { Corrected vision } \\
\text { upon optic } \\
\text { atrophy surgery. }\end{array}$ \\
\hline $\begin{array}{l}\text { Fischer- } \\
\text { Zirnsak } \\
\text { et al. [7] }\end{array}$ & $\begin{array}{l}\text { Heterozygous } \\
\text { P: c. } 5714 \mathrm{G}>\mathrm{A} \\
\text { M: c. } 2827 \mathrm{G}>\mathrm{T}\end{array}$ & $\begin{array}{l}\text { Facial } \\
\text { dysmorphism; } \\
\text { short stature; } \\
\text { senile skin; small } \\
\text { hands and feet } \\
\text { (micromelia and } \\
\text { brachydactyly); } \\
\text { bone dystrophy; } \\
\text { muscular } \\
\text { hypotonia }\end{array}$ & $\begin{array}{l}\text { Elevated LFTs with } \\
\text { episodes of pyrexia; } \\
\text { hypogammaglobulinemia; } \\
\text { reduced B lymphocytes; } \\
\text { optic atrophy; Pelger-Huet } \\
\text { anomaly }\end{array}$ & $\begin{array}{l}\text { Regular IVIG } \\
\text { Immunoglobulin } \\
\text { replacement } \\
\text { therapy }\end{array}$ & $\begin{array}{l}\text { Improved quality } \\
\text { of life following } \\
\text { immunological } \\
\text { treatment, where } \\
\text { the patient } \\
\text { stopped having } \\
\text { recurrent } \\
\text { candida tonsilitis } \\
\text { and HSV } \\
\text { infections }\end{array}$ \\
\hline $\begin{array}{l}\text { Maksimo } \\
\text { va et al. } \\
{[8]}\end{array}$ & $\begin{array}{l}\text { Heterozygous } \\
\text { P: c. } 6496- \\
6497 i n s A \\
\text { M: c. } 5741 \mathrm{G}>\mathrm{A}\end{array}$ & $\begin{array}{l}\text { Facial } \\
\text { dysmorphism; } \\
\text { short stature; } \\
\text { senile skin; } \\
\text { developmental } \\
\text { delay; skeletal } \\
\text { anomalies; } \\
\text { hepatosplenomeg } \\
\text { aly }\end{array}$ & $\begin{array}{l}\text { Elevated LFTs with } \\
\text { episodes of pyrexia and } \\
\text { recurrent infections; } \\
\text { hypogammaglobulinemia; } \\
\text { elevated CD19 B cells; bone } \\
\text { marrow smear showed } \\
\text { hypoplasia in erythroid } \\
\text { cells; osteoporosis; optic } \\
\text { atrophy; Pelger-Huet } \\
\text { anomaly }\end{array}$ & $\begin{array}{l}\text { Antipyretic } \\
\text { treatment to } \\
\text { minimize liver } \\
\text { damage; } \\
\text { prophylactic } \\
\text { antibiotic; Regular } \\
\text { IVIG } \\
\text { Immunoglobulin } \\
\text { replacement } \\
\text { therapy; extensive } \\
\text { follow up in } \\
\text { specialized } \\
\text { departments; } \\
\text { bisphosphonates to } \\
\text { manage } \\
\text { osteoporosis }\end{array}$ & $\begin{array}{l}\text { Improved life } \\
\text { expectancy due } \\
\text { to antipyretic } \\
\text { liver treatment }\end{array}$ \\
\hline
\end{tabular}




\begin{tabular}{|c|c|c|c|c|c|}
\hline $\begin{array}{l}\text { Maksimo } \\
\text { va et al. } \\
\text { [9] }\end{array}$ & $\begin{array}{l}\text { Heterozygous } \\
\text { P: } \\
\text { C.500_501delT } \\
\text { T } \\
\text { M: c.5752A>C }\end{array}$ & $\begin{array}{l}\text { Facial } \\
\text { dysmorphism; } \\
\text { short stature; } \\
\text { small hands and } \\
\text { feet (micromelia } \\
\text { and } \\
\text { brachydactyly) }\end{array}$ & $\begin{array}{l}\text { Elevated LFTs with } \\
\text { episodes of pyrexia and } \\
\text { recurrent infections; } \\
\text { hypogammaglobulinemia; } \\
\text { optic nerve atrophy; Pelger- } \\
\text { Huet anomaly }\end{array}$ & $\begin{array}{l}\text { Regular IVIG } \\
\text { Immunoglobulin } \\
\text { replacement } \\
\text { therapy }\end{array}$ & $\begin{array}{l}\text { Improved quality } \\
\text { of life following } \\
\text { immunological } \\
\text { treatment }\end{array}$ \\
\hline $\begin{array}{l}\text { Mégarba } \\
\text { né et al. } \\
{[10]}\end{array}$ & $\begin{array}{l}\text { Heterozygous } \\
\text { P: c.3158A }>\text { G } \\
\text { M: c.295odelA }\end{array}$ & $\begin{array}{l}\text { Facial } \\
\text { dysmorphism; } \\
\text { short stature; } \\
\text { senile skin; } \\
\text { developmental } \\
\text { delay; skeletal } \\
\text { anomalies; } \\
\text { hepatomegaly }\end{array}$ & $\begin{array}{l}\text { Elevated LFTs with } \\
\text { episodes of pyrexia and } \\
\text { recurrent infections; } \\
\text { hypogammaglobulinemia; } \\
\text { optic nerve atrophy; Pelger- } \\
\text { Huet anomaly }\end{array}$ & $\begin{array}{l}\text { Standard } \\
\text { management for } \\
\text { acute respiratory } \\
\text { infection }\end{array}$ & $\begin{array}{l}\text { Proper } \\
\text { management of } \\
\text { acute respiratory } \\
\text { infection } \\
\text { minimised } \\
\text { respiratory } \\
\text { depression and } \\
\text { related } \\
\text { complications }\end{array}$ \\
\hline $\begin{array}{l}\text { Kunishi } \\
\text { maet al. } \\
{[11]}\end{array}$ & $\begin{array}{l}\text { Heterozygous } \\
\text { P: c.1018G }>C \\
\text { M: c. } 2674 G>T\end{array}$ & $\begin{array}{l}\text { Short stature; } \\
\text { hepatomegaly; } \\
\text { developmental } \\
\text { delay }\end{array}$ & $\begin{array}{l}\text { Elevated LFTs with } \\
\text { episodes of pyrexia and } \\
\text { infections ( } 2 \text { ALF episodes); } \\
\text { Elevated lymphocytes w/ } \\
\text { left shift; Severe } \\
\text { coagulopathy (elevated PT, } \\
\text { INR, APTT); renal } \\
\text { dysfunction (elevated Cre \& } \\
\text { BUN); cytokine storm } \\
\text { (elevated IL-6 \& neopterin); } \\
\text { bone marrow aspiration } \\
\text { shows hypercellularity w/ } \\
\text { hemophagocytosis; Pelger- } \\
\text { Huet anomaly }\end{array}$ & $\begin{array}{l}\text { Early antipyretic } \\
\text { therapy with } \\
\text { acetaminophen \& } \\
\text { glucose infusion } \\
\text { Intensive treatment } \\
\text { during liver crises: } \\
\text { Plasmapheresis, } \\
\text { haemodialysis, IV } \\
\text { antibiotics, IVIG, } \\
\text { glucose infusion }\end{array}$ & $\begin{array}{l}\text { Improved life } \\
\text { expectancy due } \\
\text { to antipyretic } \\
\text { liver treatment }\end{array}$ \\
\hline $\begin{array}{l}\text { Park and } \\
\text { Lee [12] }\end{array}$ & $\begin{array}{l}\text { Homozygous } \\
\text { c. } 1948 \mathrm{C}>\mathrm{T}\end{array}$ & $\begin{array}{l}\text { Facial } \\
\text { dysmorphism; } \\
\text { short stature; } \\
\text { senile skin; small } \\
\text { hands and feet } \\
\text { (specifically } \\
\text { brachydactyly); } \\
\text { hepatosplenomeg } \\
\text { aly }\end{array}$ & $\begin{array}{l}\text { Elevated LFTs with } \\
\text { episodes of pyrexia; absent } \\
\text { KREC \& normal TREC } \\
\text { (crucial in the formation of } \\
T \text { - and B-cell receptors); } \\
\text { absent CD19+ cells, low } \\
\text { CD8+ lymphocytes \& NK } \\
\text { cells; }\end{array}$ & $\begin{array}{l}\text { Regular IVIG } \\
\text { Immunoglobulin } \\
\text { replacement } \\
\text { therapy \& } \\
\text { antimicrobial } \\
\text { prophylaxis; } \\
\text { corticosteroid } \\
\text { therapy }\end{array}$ & $\begin{array}{l}\text { Improved } \\
\text { functions of the } \\
\text { immune system, } \\
\text { where there are } \\
\text { significant } \\
\text { improvements in } \\
\text { gastrointestinal } \\
\text { and cutaneous } \\
\text { manifestations of } \\
\text { eczema as well as } \\
\text { the reduction of } \\
\text { hypereosinophili } \\
\text { a }\end{array}$ \\
\hline $\begin{array}{l}\text { He et al. } \\
{[13]}\end{array}$ & $\begin{array}{l}\text { Heterozygous } \\
\text { c.1628_1629in } \\
\text { sA } \\
\text { c. } 5741 \mathrm{G}>\mathrm{A} \\
\text { (undefined } \\
\text { inheritance) }\end{array}$ & $\begin{array}{l}\text { Facial } \\
\text { dysmorphism; } \\
\text { skeletal dysplasia; } \\
\text { osteoporosis; } \\
\text { short stature; } \\
\text { developmental } \\
\text { delay; senile skin; } \\
\text { muscular } \\
\text { hypotonia }\end{array}$ & $\begin{array}{l}\text { Elevated LFTs with } \\
\text { episodes of pyrexia and } \\
\text { recurrent infections; } \\
\text { hypogammaglobulinemia; } \\
\text { low T-cells; low B-cells; } \\
\text { thrombocytopenia; optic } \\
\text { nerve atrophy; Pelger-Huet } \\
\text { anomaly }\end{array}$ & $\begin{array}{l}\text { Regular IVIG } \\
\text { Immunoglobulin } \\
\text { replacement } \\
\text { therapy \& } \\
\text { antimicrobial } \\
\text { prophylaxis; } \\
\text { corticosteroid } \\
\text { therapy; } \\
\text { gastrostomy to } \\
\text { manage of hepatic } \\
\text { encephalopathy }\end{array}$ & $\begin{array}{l}\text { Enhanced } \\
\text { immunological } \\
\text { functions and the } \\
\text { ultimate } \\
\text { improvement of } \\
\text { life quality and } \\
\text { life expectancy. }\end{array}$ \\
\hline
\end{tabular}




\section{Conclusion}

In conclusion, we report a pair of novel biallelic heterozygous NBAS mutations present in introns that were previously unreported, and the association of Fanconi syndrome with SOPH. As the mutations c.5139-5T>G and c.2203-2A $>\mathrm{G}$ were shown to influence disease severity by not only affecting liver function and skeletal muscles but also contributing to immunodeficiencies, our study supports the renaming of SOPH to SOPHIA, an acronym for Skeletal-OcularPelger-Huet-Immunology-Acute liver failure syndrome, as proposed by Lacassie et al. [1]. We strongly believe that this acronym would allow future physicians to detect this syndrome more easily and hence, administer effective treatment, as $\mathrm{SOPH}$ emcompasses a wide range of expressions oftentimes requiring a multidisciplinary approach; especially the presence of immunodeficiencies,an under-recognized presentation in SOPH, should be recognized early on to improve their patients' prognoses.

\section{Acknowledgements}

Jia Yean Thong, Zifeng Li, Alice Halim and Michael Halim contributed equally to the research and writing of this case report.

\section{Consent Letter}

We sincerely thank our patient and her parents for their wholehearted support in our research, and we hope that it will not only benefit other patients with similar conditions, but more importantly contribute to the field of medicine.

\section{References}

[1] Lacassie Y, Johnson B, Lay-Son G, Quintana R, King A, Cortes F, Alvarez C, Gomez R, Vargas A, Chalew S, King A, Guardia S, Sorensen RU, Aradhya S. Severe SOPH syndrome due to a novel NBAS mutation in a 27year-old woman-Review of this pleiotropic, autosomal recessive disorder: Mystery solved after two decades. Am J Med Genet A. 2020 Jul;182(7):1767-75. [PMID: 32297715]

[2] Maksimova N, Hara K, Nikolaeva I, Chun-Feng T, Usui T, Takagi M, Nishihira Y, Miyashita A, Fujiwara H, Oyama T, Nogovicina A, Sukhomyasova A, Potapova S, Kuwano R, Takahashi H, Nishizawa M, Onodera O. Neuroblastoma amplified sequence gene is associated with a novel short stature syndrome characterised by optic nerve atrophy and Pelger-Huët anomaly. J Med Genet. 2010 Aug;47(8):538-48. [PMID: 20577004]

[3] Segarra NG, Ballhausen D, Crawford H, Perreau M, Campos-Xavier B, van Spaendonck-Zwarts K, Vermeer C, Russo M, Zambelli PY, Stevenson B, Royer-Bertrand B, Rivolta C, Candotti F, Unger S, Munier FL, SupertiFurga A, Bonafé L. NBAS mutations cause a multisystem disorder involving bone, connective tissue, liver, immune system, and retina. Am J Med Genet A. 2015 Dec;167A(12):2902-12. [PMID: 26286438]

[4] Haack TB, Staufner C, Köpke MG, Straub BK, Kölker S, Thiel C, Freisinger P, Baric I, McKiernan PJ, Dikow N, Harting I, Beisse F, Burgard P, Kotzaeridou U, Kühr J, Himbert U, Taylor RW, Distelmaier F, Vockley J, Ghaloul-Gonzalez L, Zschocke J, Kremer LS, Graf E, Schwarzmayr T, Bader DM, Gagneur J, Wieland T, Terrile C, Strom TM, Meitinger T, Hoffmann GF, Prokisch H. Biallelic Mutations in NBAS Cause Recurrent Acute Liver Failure with Onset in Infancy. Am J Hum Genet. 2015 Jul 2;97(1):163-69. [PMID: 26073778]

[5] Capo-Chichi JM, Mehawej C, Delague V, Caillaud C, Khneisser I, Hamdan FF, Michaud JL, Kibar Z, Mégarbané A. Neuroblastoma Amplified Sequence (NBAS) mutation in recurrent acute liver failure: Confirmatory report in a sibship with very early onset, osteoporosis and developmental delay. Eur J Med Genet. 2015 Dec;58(12):637-41. [PMID: 26578240]

[6] Kortüm F, Marquardt I, Alawi M, Korenke GC, Spranger S, Meinecke P, Kutsche K. Acute Liver Failure Meets SOPH Syndrome: A Case Report on an Intermediate Phenotype. Pediatrics. 2017 Jan;139(1):e20160550. [PMID: 28031453]

[7] Fischer-Zirnsak B, Koenig R, Alisch F, Güneş N, Hausser I, Saha N, Beck-Woedl S, Haack TB, Thiel C, Kamrath C, Tüysüz B, Henning S, Mundlos S, Hoffmann K, Horn D, Kornak U. SOPH syndrome in three affected individuals showing similarities with progeroid cutis laxa conditions in early infancy. J Hum Genet. 2019 Jul;64(7):6o9-16. [PMID: 31015584]

[8] Maksimova NR, Nogovicina AN, Kurtanov KA, Alekseeva EI. [Population frequency and age of mutation $\mathrm{G}_{5741} \rightarrow \mathrm{A}$ in gene NBAS which is a cause of SOPH syndrome in Sakha (Yakutia) Republic]. 
Genetika. 2016 Oct;52(10):1194-201. Russian. [PMID: 29369590]

[9] Maksimova N, Hara K, Miyashia A, Nikolaeva I, Shiga A, Nogovicina A, Sukhomyasova A, Argunov V, Shvedova A, Ikeuchi T, Nishizawa M, Kuwano R, Onodera O. Clinical, molecular and histopathological features of short stature syndrome with novel CUL7 mutation in Yakuts: new population isolate in Asia. J Med Genet. 2007 Dec;44(12):772-78. [PMID: 17675530]

[10] Mégarbané A, Samaras L, Chédid R, Chouery E, Chrétien D, Caillaud C, Abou-Ghoch J, Jalkh N. Developmental delay, dysmorphic features, neonatal spontaneous fractures, wrinkled skin, and hepatic failure: a new metabolic syndrome? Am J Med Genet A. 2008 Dec 15;146A(24):3198-201. [PMID: 19012336]

[11] Kunishima S, Okuno Y, Yoshida K, Shiraishi Y, Sanada M, Muramatsu H, Chiba K, Tanaka H, Miyazaki K, Sakai M, Ohtake M, Kobayashi R, Iguchi A, Niimi G, Otsu M, Takahashi Y, Miyano S, Saito H, Kojima S, Ogawa S. ACTN1 mutations cause congenital macrothrombocytopenia. Am J Hum Genet. 2013 Mar 7;92(3):431-38. [PMID: 23434115]

[12] Li W, Zhu Y, Guo Q, Wan C. Infantile fevertriggered acute liver failure caused by novel neuroblastoma amplified sequence mutations: a case report. BMC Gastroenterol. 2020 Sep 21;20(1):308. [PMID: 32957979]

[13] He TY, Zhang N, Xia Y, Luo Y, Li CR, Yang J. [Short stature, optic nerve atrophy and Pelger-Huët anomaly syndrome with antibody immunodeficiency and aplastic anemia: a case report and literature review]. Zhonghua $\mathrm{Er}$ Ke $\mathrm{Za}$ Zhi. 2017 Dec 2;55(12):942-46. Chinese. [PMID: 29262476]

[14] Li X, Cheng Q, Li N, Chang G, Ding Y, Li J, Shen Y, Wang J, Wang X. SOPH Syndrome with Growth Hormone Deficiency, Normal Bone Age, and Novel Compound Heterozygous Mutations in NBAS. Fetal Pediatr Pathol. 2018 Dec;37(6):404-10. [PMID: 30592236]

[15] Nucci F, Lembo A, Farronato M, Farronato G, Nucci P, Serafino M. Oculofacial alterations in NBASSOPH like mutations: Case report. Eur J Ophthalmol. 2020 Mar;30(2):NP12-NP15. [PMID: 30845840]

[16] Karatzas A, Paridis D, Kozyrakis D, Tzortzis V, Samarinas M, Dailiana Z, Karachalios T. Fanconi syndrome in the adulthood. The role of early diagnosis and treatment. J Musculoskelet Neuronal Interact. 2017 Dec 1;17(4):303-306. [PMID: 29199190]

[17] Keefe P, Bokhari SRA. Fanconi Syndrome. 2020 Jul 10. In: StatPearls [Internet]. Treasure Island (FL): StatPearls Publishing; 2020 Jan. [PMID: 30521293] [18] Ono S, Matsuda J, Watanabe E, Akaike H, Teranishi H, Miyata I, Otomo T, Sadahira Y, Mizuochi T, Kusano H, Kage M, Ueno H, Yoshida K, Shiraishi Y, Chiba K, Tanaka H, Miyano S, Ogawa S, Hayashi Y, Kanegane H, Ouchi K. Novel neuroblastoma amplified sequence (NBAS) mutations in a Japanese boy with fever-triggered recurrent acute liver failure. Hum Genome Var. 2019 Jan 7;6:2. [PMID: 30622725]

[19] Calvo PL, Tandoi F, Haak TB, Brunati A, Pinon M, Olio DD, Romagnoli R, Spada M. NBAS mutations cause acute liver failure: when acetaminophen is not a culprit. Ital J Pediatr. 2017 Sep 25;43(1):88. [PMID: 28946922]

[20] Wang J, Pu Z, Lu Z. Targeted next-generation sequencing reveals two novel mutations of NBAS in a patient with infantile liver failure syndrome-2. Mol Med Rep. 2018 Feb;17(2):2245-50. [PMID: 29207168] [21] Dayan RR, Bignall Ii ONR, Johnson S, Flores F, Volovelsky O. Neuroblastoma Amplified Sequence Gene Mutations Inducing Acute Kidney and Liver Injury in an Adolescent Female. Case Rep Nephrol Dial. 2020 Oct 13;10(3):117-23. [PMID: 33173785] [22] Li JQ, Qiu YL, Gong JY, Dou LM, Lu Y, Knisely AS, Zhang MH, Luan WS, Wang JS. Novel NBAS mutations and fever-related recurrent acute liver failure in Chinese children: a retrospective study. BMC Gastroenterol. 2017 Jun 19;17(1):77. [PMID: 28629372] [23] Hasosah MY, Iskandarani AI, Shawli AI, Alsahafi AF, Sukkar GA, Qurashi MA. Neuroblastoma amplified sequence gene mutation: A rare cause of recurrent liver failure in children. Saudi J Gastroenterol. 2017 May-Jun;23(3):206-208. [PMID: 28611345]

[24] Staufner C, Haack TB, Köpke MG, Straub BK, Kölker S, Thiel C, Freisinger P, Baric I, McKiernan PJ, Dikow N, Harting I, Beisse F, Burgard P, Kotzaeridou U, Lenz D, Kühr J, Himbert U, Taylor RW, Distelmaier F, Vockley J, Ghaloul-Gonzalez L, Ozolek JA, Zschocke J, Kuster A, Dick A, Das AM, Wieland T, Terrile C, Strom TM, Meitinger T, Prokisch H, Hoffmann GF. Recurrent acute liver failure due to NBAS deficiency: phenotypic spectrum, disease mechanisms, and therapeutic concepts. J Inherit Metab Dis. 2016 Jan;39(1):3-16. 
[PMID: 26541327]

[25] Balasubramanian M, Hurst J, Brown S, Bishop NJ, Arundel P, DeVile C, Pollitt RC, Crooks L, Longman D, Caceres JF, Shackley F, Connolly S, Payne JH, Offiah AC, Hughes D; DDD Study, Parker MJ, Hide W, Skerry TM. Compound heterozygous variants in NBAS as a cause of atypical osteogenesis imperfecta. Bone. 2017 Jan;94:65-74. [PMID: 27789416]

[26] Regateiro FS, Belkaya S, Neves N, Ferreira S, Silvestre P, Lemos S, Venâncio M, Casanova JL, Gonçalves I, Jouanguy E, Diogo L. Recurrent elevated liver transaminases and acute liver failure in two siblings with novel bi-allelic mutations of NBAS. Eur J Med Genet. 2017 Aug;6o(8):426-32. [PMID: 28576691]

[27] Sunwoo Y, Kim YM, Kim EN, Oh SH, Lee BH. Severe form of neuroblastoma amplified sequence deficiency in an infant with recurrent acute liver failure. Pediatr Int. 2018 Mar;6o(3):302-304. [PMID: 29575310]

[28] Palagano E, Zuccarini G, Prontera P, Borgatti R, Stangoni G, Elisei S, Mantero S, Menale C, Forlino A,
Uva P, Oppo M, Vezzoni P, Villa A, Merlo GR, Sobacchi C. Mutations in the Neuroblastoma Amplified Sequence gene in a family affected by Acrofrontofacionasal Dysostosis type 1. Bone. 2018 Sep;114:125-36. [PMID: 29929043]

[29] Strom SP, Lee H, Das K, Vilain E, Nelson SF, Grody WW, Deignan JL. Assessing the necessity of confirmatory testing for exome-sequencing results in a clinical molecular diagnostic laboratory. Genet Med. 2014 Jul;16(7):510-15. [PMID: 24406459]

[30] Khoreva A, Pomerantseva E, Belova N, Povolotskaya I, Konovalov F, Kaimonov V, Gavrina A, Zimin S, Pershin D, Davydova N, Burlakov V, Viktorova E, Roppelt A, Kalinina E, Novichkova G, Shcherbina A. Complex Multisystem Phenotype With Immunodeficiency Associated With NBAS Mutations: Reports of Three Patients and Review of the Literature. Front Pediatr. 2020 Sep 15;8:577. [PMID: 33042920] [31] Shah NJ, Royer A, John S. Acute Liver Failure. 2020 Nov 20. In: StatPearls [Internet]. Treasure Island (FL): StatPearls Publishing; 2020 Jan. [PMID: 29493996]

Keywords: Short Stature, Optic Atrophy, Pelger-Huet Anomaly, Neuroblastoma Amplified Sequence, Mutation, WholeGenome Sequencing, Myopia, Case Report, Acute Liver Failure, Fanconi Syndrome 